\title{
Tony Delsham, Chauve qui peut à Schœelcher. Comédie policière
}

\section{Paola Ghinelli}

\section{(2) OpenEdition}

10 Journals

\section{Édition électronique}

URL : https://journals.openedition.org/studifrancesi/38477

DOI : 10.4000/studifrancesi.38477

ISSN : 2421-5856

Éditeur

Rosenberg \& Sellier

\section{Édition imprimée}

Date de publication : 15 décembre 2004

Pagination : 664

ISSN : 0039-2944

\section{Référence électronique}

Paola Ghinelli, «Tony Delsham, Chauve qui peut à Schœlcher. Comédie policière », Studi Francesi [En ligne], 144 (XLVIII | III) | 2004, mis en ligne le 30 novembre 2015, consulté le 08 mai 2021. URL : http:// journals.openedition.org/studifrancesi/38477 ; DOI : https://doi.org/10.4000/studifrancesi.38477

Ce document a été généré automatiquement le 8 mai 2021.

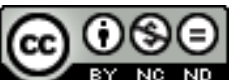

Studi Francesi è distribuita con Licenza Creative Commons Attribuzione - Non commerciale - Non opere derivate 4.0 Internazionale. 


\title{
Tony Delsham, Chauve qui peut à schœlcher. Comédie policière
}

\author{
Paola Ghinelli
}

\section{RÉFÉRENCE}

TONY DELSHAM, Chauve qui peut à Schœelcher. Comédie policière, Schœlcher, Martinique Éditions, 2003, pp. 242.

1 Qui distribue des armes de guerre aux indépendantistes des Antilles françaises, risquant ainsi de provoquer une crise internationale, et pourquoi? C'est un cas pour William Charlebois (surnommé W.C.!) et son ex collègue martiniquais Pierre Corneille, entrainé malgré lui dans la solution de ce cas difficile dont le scénario est son île natale. Après de rocambolesques aventures, des intrigues et des trahisons, tous les méchants mourront et leur plan diabolique sera éventé en ne laissant qu'un doute, à Pierre Corneille, détective d'exception. Voici, en quelques mots, l'intrigue que nous propose Tony Delsham, un des rares auteurs martiniquais à être publié en Martinique. Tout en étant relativement peu connu en Europe par rapport à ses collègues édités à Paris, cet auteur est célèbre dans son île natale, et malgré les limites de son talent, il mérite d'être considéré avec attention pour son effort de se pencher sur les problèmes actuels du D.O.M. Comme tout romancier véritablement populaire, Tony Delsham met en scène dans ses romans tous les stéréotypes que ceux qui aspirent à une dignité critique essaient d'éviter.

2 Et pourtant, sans doute parce que les stéréotypes constituent un des principaux ressorts des romans policiers, Chauve qui peut à Schoelcher se lit volontiers. L'intrigue invraisemblable fournit un prétexte à l'auteur pour peindre des portraits grotesques ou attendris de certains «types» martiniquais, ou pour éclairer certaines manies facilement reconnaissables dans la société actuelle. Les références trop fréquentes, presque didactiques, à l'actualité socio-politique martiniquaise qui caractérisent les romans de Delsham, sont dans ce cas acceptables, car elles s'insèrent dans un contexte 
satirique, comme le montre le titre lui-même, un clin d'œil à la célèbre gaffe du ministre des libertés locales en visite à la Martinique. Les traductions des phrases créoles et les explications que l'auteur multiplie, en contestation ouverte avec la notion d'opacité des romanciers de la créolité, n'alourdissent pas ce roman de manière excessive, étant motivées par une raison intra diégétique: l'un des détectives est en fait un «Français-de-France», qui ne connait rien des Antilles. Même les figures de femmes, très aplaties et stéréotypées comme elles le sont fréquemment dans les romans de cet auteur, conviennent à un contexte humoristique et à un détective macho. Delsham a peut-être trouvé le ton qui convient le mieux à son écriture, une auto-ironie qui lui a fait souvent défaut, pour parvenir à nous offrir un roman sur la contemporanéité antillaise, léger et amusant sans être exotique à tout prix. 